\section{An evaluation on corporate social responsibility involvement among the golf courses and country clubs in the Philippines}

Vizconde, Angelie Marie L. $\triangle$

Manila Tytana Colleges, Philippines (alvizconde@mtc.edu.ph)

Received: 5 December 2020

Available Online: 12 January 2021
Revised: 22 December 2020 DOI: $10.5861 /$ ijrsm.2021.7701

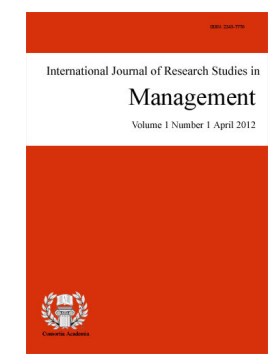

ISSN: $2243-7770$ Online ISSN: 2243-7789

Accepted: 4 January 2021

OPEN ACCESS

\title{
Abstract
}

By strengthening the corporate social responsibility, companies not only can benefit from today's profits, but also consolidate their success and positions in the future as well. This study aims to evaluate the CSR involvement among the employees and guest of Golf Courses and Country Clubs in the Philippines in terms of environmental activity, volunteering, and goodwill. A quantitative descriptive method was use using the random sampling technique to 298 respondents. The results revealed that in terms of environmental effort have positive responses because the guest, employees and top management were involved. Respondents from Laguna have a significantly higher response to CSR participation in an environmental activity, volunteering, and goodwill whereas employees who earned 36,000 to 40,000 have significantly higher level of CSR involvement in terms of goodwill. Result showed that the group of guests with less than Php 100,000 income has significantly higher level of response in the level of involvement of the Golf Course compared to other income groups. It was recommended to develop holistic and comprehensive sustainable community-based development plan and strategies for the CSR projects, activities and practices of golf course and country clubs in the Philippines in partnership for the benefit of the society.

Keywords: environmental; practices; goodwill; sustainability; volunteering 


\section{An evaluation on corporate social responsibility involvement among the golf courses and country clubs in the Philippines}

\section{Introduction}

Corporate Social Responsibility may refer to corporate still, mini voice, citizenship, social execution, or feasible capable networks is a definition of corporate self-guideline incorporated into a plan of action. On the year 2018, the Golf Commerce International expressed that Corporate Social Responsibility (CSR) is the proceeding commitment by organizations to act morally and contribute to social and financial improvement additionally making strides the quality of life of staff, volunteers, and the neighborhood community and society at expansive. The goals of CSR are to grasp responsible regarding the programs activities and support a positive effect through its activities on the earth, shoppers, employees, partner and all the individuals from the open arena.

As discussed in the article of Stawiski et al. (2010) that there is still no difference in the amount that CSR contributes to organizational commitment for members of each generation even after resounding the insignificant difference among the generations about perceptions of how socially responsible their corporations are. Furthermore, the CSR is similarly and positively related to commitment for Gen X'ers and both early and late boomers. The result is consistent with other research that most working adults want the same things at work and are committed to their organizations for significantly the same reasons.

In the journal of business ethics written by Suy (2016), which talks about recognizing corporate social responsibility as part of the business operational management. This journal cited that in CSR behind motives, the retention, employee morale, and recruitment, with the acknowledged employees is the key on an organizational partner. In addition, according to Ahmad, Rahman, and Anumar (2018), illustrate the corporate social responsibility (CRS) refers to the act of the corporates giving back in kind to society as tasks that advantage the less special people from the site where the business is organized. Along these programs are conformed to advance socially cognizant strategic policies and give assists to its time. As large numbers of the organization are social and ecological in nature though inside the program could likewise show its anxiety to issue of basic human rights and workers government helper as a feature of its CSR exercises.

This study aims to evaluate the CSR involvement among the employees and guest of Golf Courses and Country Clubs in the Philippines in terms of environmental activity, volunteering, and goodwill. To determine the significant difference on the response when grouped according to profile and suggest recommendations for continuous improvement for the Golf Courses and Country Clubs based on the result of the study.

\section{Corporate Social Responsibility}

The research of Borbon (2019) corporate social responsibility is evolving within the four key and primary responsibilities. Economic describes the capacity of the corporation to be financially viable, lawful, concerned primarily with obeying the law; ethical is concerned with knowing what reasonable and proper and philanthropic portrayals is being a responsible corporate citizen (Carroll, 1983; Dudovskiy, 2012). In pyramid, these four duties can be seen to see the multiple aspects of Corporate Social Responsibility. This basic frame of Carroll has many options that enable audiences to understand the fundamental idea of Corporate Social Responsibility. One characteristic is that revenue should come initially, as the economic responsibility lies at the bottom of most of the hierarchy that serves as the firm's major foundation. The enterprise would not be able to obtain the other three responsibilities without being financially beneficial. Once the company is liquidated, it ensures that the business complies with the rules and regulations, as it is the second responsibility to fill in. The third accountability is to behave morally by measuring the standards and values of the business, on the other hand, the 
An evaluation on CSR involvement among the golf courses and country clubs in the Philippines

central feature of the pyramid is to give back to the community which is marked as the finest level of Corporate Social Responsibility, this responsibility is contractual but important and thus encourages the industry to practice.

\subsection{Environmental effort}

In the discussion of Melo and Garrido (2012), their recommendation is to initiate corporate social responsibility (CSR) is a key driver of corporate distinction given its capability to cultivate hard-to-copy competitive edge. They introduced distinctive model that contains the multidimensional idea of CSR, introducing a five-dimensional construct- employee relations, diversity issues, product issues, community relations, and environmental issues - and interact those with industrial effects. As results of the study, it demonstrates that the five components of CSR significantly affect corporate notability and this impact is directed by the business of the firm.

\subsection{Volunteering}

The worker volunteerism is an act of corporate social obligation of the green and nation clubs that fortifying the representative fulfillment and maintenance inside and reinforcing the notorieties and associations with partners remotely. Based on the study of Cycyota et al. (2016), volunteered employees practice corporate social responsibility and help corporations by strengthening employee fulfillment and retention internally and corporate reputations and associations with partners externally. Specific practices and procedures utilized by companies to empower and support volunteer activities of their employees are of interest. Based on the findings, most companies connect employee volunteerism to their Corporate Social Responsibility strategy to encourage and support the said practice.

\subsection{Goodwill}

In article distributed by Gathering Pacific Consolidated (2018), has supported a blessing giving program final at December 14, 2018 entitled, "The Favoring of Giving" in another arm of "Ang Bahay Parola" which is the Peace Domestic Center for Young ladies in Sta. Rosa, Laguna. The company conducted recreations and given out blessings and nourishments to the children and staffs, In return, the children gave a hearth warming execution as a way of saying thank you to the company/taking socially mindful activities with the trade is genuinely a win-win circumstance. Not as it were the company offer to progressively socially cognizant buyers and representatives, but it'll make a real distinction within the world. In the CSR, straightforwardness, and genuineness approximately what the company is doing are vital to gaining the publics believe. CSR can include a wide assortment of strategies from giving non-profit organizations a parcel of a company's benefits, to giving absent items of benefit to a commendable recipient.

\section{Methods}

This study aims to evaluate the CSR involvement among the employees and guest of Golf Courses and Country Clubs in the Philippines in terms of environmental activity, volunteering, and goodwill. A quantitative descriptive method was use using the random sampling technique to 298 respondents. The data was collected through self-administering of the survey questionnaire among the golf courses and country clubs in various provinces in the Philippines. The Data was encoded, tallied and treated through SPSS. Frequency Distribution and Percentage is used to present the profile of the respondents while weighted mean and rank is used to assess the CSR Involvement in terms of environmental activity, volunteering, and goodwill. T-test and analysis of variance (anova) was used to determine the significant difference among the response when grouped according to profile. 


\section{Result and discussion}

\section{Table 1}

Profile of the respondents

\begin{tabular}{clcc}
\hline \multicolumn{1}{c}{ Profile } & & Frequency & Percent \\
\hline Location & Metro Manila & 120 & 40.3 \\
& Cavite & 118 & 39.6 \\
& Batangas & 30 & 10.1 \\
& Laguna & 30 & 10.1 \\
\hline Income (employees) & 20,000 and below & 49 & 16.4 \\
& $21,000-25,000$ & 31 & 10.4 \\
& $26,000-30,000$ & 14 & 4.7 \\
& $31,000-35,000$ & 11 & 3.7 \\
& $36,000-40,000$ & 6 & 2.0 \\
& $41,000-50,000$ & 33 & 11.1 \\
\hline Income (Guests) & $51,000-100,000$ & 55 & 18.5 \\
& $101,000-150,000$ & 51 & 17.1 \\
& 151,000 and above & 48 & 16.1 \\
\hline
\end{tabular}

Table 1 show that most of the respondents are from Metro Manila with regards to the location. As for the income of the participants, majority of the respondents who are the employees of golf course received salary 20,000.00 and below. Meanwhile, for the responses from the guests it is shows that most of the guests received and income range from 51,000.00-100,000.00.

Table 2

CSR involvement in terms of environmental effort

\begin{tabular}{|c|c|c|c|c|c|c|c|}
\hline & Environmental effort & WM & & NI & SI & $\mathrm{I}$ & HI \\
\hline \multirow[t]{2}{*}{1.} & I am involved in the staff morale and skills & 2.79 & $\mathrm{f}$ & 34 & 88 & 82 & 94 \\
\hline & $\begin{array}{l}\text { development through CSR projects, activities and } \\
\text { practices of the golf course }\end{array}$ & I & $\%$ & 11.4 & 29.5 & 27.5 & 31.5 \\
\hline \multirow[t]{2}{*}{2.} & I am involved in building harmonious relationships & 2.77 & $\mathrm{f}$ & 33 & 99 & 69 & 97 \\
\hline & $\begin{array}{l}\text { between the golf course with the local community, } \\
\text { partners and clients through CSR projects, activities } \\
\text { and practices }\end{array}$ & I & $\%$ & 11.1 & 33.2 & 23.2 & 32.6 \\
\hline \multirow[t]{2}{*}{3.} & I am involved in the innovation processes, products & 2.74 & $f$ & 37 & 96 & 73 & 92 \\
\hline & $\begin{array}{l}\text { and services of golf course through CSR projects, } \\
\text { activities and practices }\end{array}$ & I & $\%$ & 12.4 & 32.2 & 24.5 & 30.9 \\
\hline \multirow[t]{2}{*}{4.} & I am involved in managing the risks a company faces & 2.75 & $\mathrm{f}$ & 36 & 93 & 79 & 90 \\
\hline & $\begin{array}{l}\text { related to corporate social responsibility projects, } \\
\text { activities and practices }\end{array}$ & I & $\%$ & 12.1 & 31.2 & 26.5 & 30.2 \\
\hline \multirow[t]{3}{*}{5.} & I am involved in maximizing customer loyalty and & 2.81 & 1 & 33 & 91 & 93 & 79 \\
\hline & $\begin{array}{l}\text { improving morale among the workforce of the golf } \\
\text { course through CSR projects, activities and practices }\end{array}$ & I & $\%$ & 11.1 & 30.5 & 31.2 & 26.5 \\
\hline & Overall Mean & 2.77 & & 11.6 & 31.4 & 26.6 & 30.4 \\
\hline
\end{tabular}

Scale. Highly Involved (HI), 3.50-4.00; Involved (I), 2.50-3.49; Slightly Involved (SI), 1.50-2.49; Not Involved, 1.00-1.49.

Table 2 shows the CSR involvement in terms of environmental effort. The computed overall mean of 2.77 means that the CSR of the golf course and country clubs in terms of environmental effort have positive responses because the guest, employees and top management were involved. There is 26.5 percent strongly agreed that the golf course as well as the country clubs in terms of environmental efforts were involved when it comes to maximizing the customers loyalty and ways to improve morale among the workforce of the golf course through CSR projects, activities and practices. Meanwhile there is a 31.5 percent strongly agreed that the golf courses involved in the staff morale and skills development through CSR projects, activities and practices of the golf course and country clubs (2.79). 
An evaluation on CSR involvement among the golf courses and country clubs in the Philippines

Likewise, there is 32.6 percent strongly agreed that the golf courses and country clubs involved in building harmonious relationships between the golf courses and country clubs involved with the local community, partners and clients through CSR projects, activities and practices (2.77). Meanwhile, the golf courses that were involved in environmental effort in managing the risks at company faces related in corporate social responsibility projects, activities and practices are strongly agreed in the percentage of 30.2 (2.75).

The respondents have a positive response that the golf courses and country clubs involved in managing the risks through reducing the impacts that can affect the organization negatively by having positive actions on the different corporate social responsibility projects, activities and practices. However, respondents agreed that they are involved in the innovation processes, products and services of golf course and country clubs through CSR projects, activities and practices (2.74) obtained the least weighted mean score with 24.5 percent and to those who strongly agreed at the percentage of 30.9 at the table. The participants have a positive response that the golf courses and country clubs involved in the innovation of processes, products and services through CSR projects, activities and practices. Innovation comes from unlikely connections.

According to Oriol Hurtado de Mendoza (2015), the common interest in corporate social responsibility have a policy that is been expanding and this is because of the crisis that are experiencing by the economy or the enlarging of the pollution and its destruction in the environment in different countries. The general public is progressively worried about its social, ecological, and financial environmental factors, while supporting mindful utilization and regard for common liberties. However, the organizations have felt obliged to improve their CSR approaches and activities. The managers who work at the company usually promote their employees as people who take cares of the society and also the environment, letting the employees show off their commitment and credibility to their brand in that case the managers can support them, until they can find the closest to the strategies, they can use to be competitive.

Table 3

CSR involvement in terms of volunteering

\begin{tabular}{|c|c|c|c|c|c|c|c|}
\hline & Volunteering & WM/VI & & $\mathrm{NI}$ & SI & $\mathrm{I}$ & $\mathrm{HI}$ \\
\hline \multirow[t]{2}{*}{1.} & I am involved in environmentally & 2.73 & $\mathrm{f}$ & 41 & 89 & 78 & 90 \\
\hline & $\begin{array}{l}\text { sustainable CSR projects, activities and } \\
\text { practices }\end{array}$ & A & $\%$ & 13.8 & 29.9 & 26.2 & 30.2 \\
\hline \multirow[t]{2}{*}{2.} & I am involved in charity programs and & 2.65 & $\mathrm{f}$ & 41 & 111 & 58 & 88 \\
\hline & donorship & $\mathrm{A}$ & $\%$ & 13.8 & 37.2 & 19.5 & 29.5 \\
\hline \multirow[t]{2}{*}{3.} & I am involved in supporting care for & 2.65 & $\mathrm{f}$ & 40 & 113 & 55 & 90 \\
\hline & $\begin{array}{l}\text { children, and other residents in the } \\
\text { community }\end{array}$ & A & $\%$ & 13.4 & 37.9 & 18.5 & 30.2 \\
\hline \multirow[t]{2}{*}{4.} & I am involved in skills-based volunteering & 2.60 & $\mathrm{f}$ & 41 & 113 & 67 & 77 \\
\hline & for the community & A & $\%$ & 13.8 & 37.9 & 22.5 & 25.8 \\
\hline \multirow[t]{3}{*}{5 . } & I am involved in community clean-up & 2.66 & $\mathrm{f}$ & 41 & 106 & 65 & 86 \\
\hline & campaigns & A & $\%$ & 13.8 & 35.6 & 21.8 & 28.9 \\
\hline & Overall Mean & 2.66 & & 13.7 & 35.7 & 21.7 & 28.9 \\
\hline
\end{tabular}

Scale. Highly Involved (HI), 3.50-4.00; Involved (I), 2.50-3.49; Slightly Involved (SI), 1.50-2.49; Not Involved, 1.00-1.49.

Table 3 presents the CSR involvement in terms of volunteering. The overall average of 2.66 suggests that the respondents have positive reaction on the contribution of respondents in the CSR in volunteering in golf courses and country clubs. Respondents affirmed that the golf course and country club are participated in sustainable environmental CSR projects, activities, and practices (2.73). Golf courses and country clubs take it together the community, staff, top management, and guests.

The respondents decided to be agreed that the golf courses and country clubs engaged with community clean-up campaigns (2.66) are a community based, ecological activity that rouses and enables networks to tidy up, fix up and moderate their condition. In addition, the golf courses and country clubs are also engaged in charity programs and donorship. Corporate philanthropy introduces itself in numerous structures and spotlights 
on numerous zones. Commitments can be in real money or in kind (commonly gave item or volunteers' time), while the rundown of potential recipients reaches out if the world's index of noble cause. An enterprise ought to oversee worker's conduct and HR choices in a way that fits the law and builds up social duty. By setting up approaches and applying them decently to all workers, an entrepreneur makes an atmosphere of reasonableness and value. Then again, offering focal points to certain workers, or playing top choices, uncovered an entrepreneur to examination over his organization's morals. It is ideal to discover a harmony between benefit-based business choices and ethical quality-based work choices. Composing ethical quality-based arrangements can make it simpler to accomplish the last mentioned (Bianca, 2018).

The training is some of the time secured inside the social exercises of organizations. Notwithstanding, in numerous nations, getting families engaged with organization (CSR) exercises as a wellspring of pride for representatives. It is a key achievement consider where the exercises are the association of the families, of the board, as this assists with drawing in lower-level representatives and make a sentiment of 'availability' to senior administration. Besides, representative volunteerism is a way of steady purposeful and dynamic giving of one's time, vitality, abilities, or gifts to an altruistic association without accepting installment consequently. Manager upheld volunteerism, specifically, is the dynamic help, through an assortment of means, for representatives chipping in with altruistic associations (Kim et al., 2020). In recent decades, volunteerism is an essential articulation of human connections. It is about individuals' have to take an interest in their social orders and to feel that they matter to other people. The social connections characteristic for charitable effort are basic to individual and network prosperity. Besides, volunteerism is the foundation of numerous public and global non-legislative associations and other common society associations, just as social and political developments. It is available in the open segment and is progressively an element of the private segment (UNDP, 2019).

\section{Table 4}

CSR involvement in terms of goodwill

\begin{tabular}{|c|c|c|c|c|c|c|c|}
\hline & Goodwill & WM/VI & & NI & SI & I & HI \\
\hline \multirow[t]{2}{*}{1.} & I am involved in the evaluation and feedback on & 2.69 & $\mathrm{f}$ & 44 & 87 & 84 & 83 \\
\hline & $\begin{array}{l}\text { CSR projects, activities, and practices of the } \\
\text { golf course to the community }\end{array}$ & A & $\%$ & 14.8 & 29.2 & 28.2 & 27.9 \\
\hline \multirow[t]{2}{*}{2.} & I am involved in motivating other employees to & 2.66 & $\mathrm{f}$ & 39 & 117 & 49 & 93 \\
\hline & $\begin{array}{l}\text { participate in CSR projects, activities and } \\
\text { practices and improve each other morale } \\
\text { through corporate social responsibility }\end{array}$ & A & $\%$ & 13.1 & 39.3 & 16.4 & 31.2 \\
\hline \multirow[t]{2}{*}{3.} & I am involved in the planning and & 2.61 & $\mathrm{f}$ & 40 & 112 & 69 & 77 \\
\hline & $\begin{array}{l}\text { implementation of CSR projects, activities and } \\
\text { practices of the golf course to the community } \\
\text { and society }\end{array}$ & A & $\%$ & 13.4 & 37.6 & 23.2 & 25.8 \\
\hline \multirow[t]{2}{*}{4.} & I am involved in the protection of natural & 2.82 & $\mathrm{f}$ & 29 & 90 & 86 & 93 \\
\hline & $\begin{array}{l}\text { resources and serve as caretaker of the } \\
\text { environment through the golf course CSR } \\
\text { projects, activities and practices }\end{array}$ & A & $\%$ & 9.7 & 30.2 & 28.9 & 31.2 \\
\hline \multirow[t]{3}{*}{5.} & I am involved in reporting the annual results of & 2.71 & $\mathrm{f}$ & 39 & 99 & 69 & 91 \\
\hline & $\begin{array}{l}\text { CSR projects, activities and practices of the golf } \\
\text { course to build momentum internally and gain } \\
\text { the public relations advantage }\end{array}$ & A & $\%$ & 13.1 & 33.2 & 23.2 & 30.5 \\
\hline & Overall Mean & 2.69 & & 12.8 & 33.9 & 24.0 & 29.3 \\
\hline
\end{tabular}

Scale. Highly Involved (HI), 3.50-4.00; Involved (I), 2.50-3.49; Slightly Involved (SI), 1.50-2.49; Not Involved, 1.00-1.49.

Table 4 shows the involvement in terms of goodwill having an overall computed of 2.69 that the country club and the golf course participants have a good response on the actions of the corporate social responsibility in terms of goodwill. There is a 31.2 percent of the participants have a positive reaction that the golf and country clubs engaged with the insurance of characteristic assets and fill in as overseer of nature through the green CSR undertakings, exercises and practices (2.82). The respondents assert that the golf course and country clubs associated with revealing the yearly consequence of CRS tasks, exercises and practices of the golf course to 
An evaluation on CSR involvement among the golf courses and country clubs in the Philippines

gather speed inside the gain the advertising advantage (2.71). The participants saw that the golf course and country club CSR has become a well know strategy for golf and country club to organize CSR and maintainability into their dynamic cycles. Similarly, the participants concurred that the gold and country club engaged with the assessment and put-on CRS task, the activity and exercises of the golf to the network (2.69). The participants have a good reaction that the golf course and country club coordinates with the CRD ventures, the activity and practices assessment, led consistently, enormously to improve the admin and viability of your coordination and its tasks, activities and practices.

The participants confirm that the gold course and country clubs associated the propelling different perspective to partake in CSR tasks, exercise and rehearses and improve each other spirit through corporate social duty (2.66). Nonetheless, engaged with the arranging and rules of CSR tasks, exercises and practices of the gold course and country club to the network and society (2.61) got the least weighted mean score. The participants confirm that the gold course and country club show that they are engaged to improve their networks through corporate giving task (like coordinating blessing and volunteer awards), they are bound to pull in the hold significant, persevering, and connected with representatives.

Furthermore, CSR is a program pledge to working in a financially, socially and ecologically seaside way while adopting the enthusiasm of different people. It expects program to search their activities and find out all potential effects just as sure commitments. The golf course and country club to have the at least two options. The golf course and country club have to have options to cultivate a moral domain for representatives and construct their certainty forward the administration according to notoriety and the kindness of the association. Actually, representatives and guest will be sure with an association that is not so sure about this employer of government helper and ready to take the undertaking of executing such strategy in compliance in common. As indicate in the article of Kulej-Dudek (2018) that the details about corporate social responsibility can be understand slowly expanding and changing supervisors think. Increasingly more golf course and country club are developing and ready to execute the CRS systems. In different case, details about the idea doesn't public convert into practice. Along these lines, the vision is there is a need to show the part of corporate social duty through functional exercises situates at accomplishment of the goal with nearby networks.

\section{Table 5}

Significant difference among CSR Involvement when grouped according to profile variable

\begin{tabular}{lccccccccc}
\hline \multicolumn{1}{c}{ Involvement } & \multicolumn{3}{c}{ Location } & \multicolumn{3}{c}{ Income of Employees } & \multicolumn{3}{c}{ Income of Guests } \\
\hline Environmental & 63.264 & .000 & $\mathrm{~S}$ & 10.728 & .057 & $\mathrm{NS}$ & 23.038 & .000 & $\mathrm{~S}$ \\
Volunteering & 52.089 & .000 & $\mathrm{~S}$ & 7.810 & .167 & $\mathrm{NS}$ & 20.363 & .000 & $\mathrm{~S}$ \\
Goodwill & 59.519 & .000 & $\mathrm{~S}$ & 13.571 & .019 & $\mathrm{~S}$ & 19.796 & .000 & $\mathrm{~S}$ \\
\hline Note. S = Significant at $p$-value $<.05$. NS $=$ non-Significant at $p$-value $>.05$.
\end{tabular}

Respondents from Laguna have a significantly higher response to CSR participation in an environmental activity, volunteering, and goodwill. In an article published by Forum Pacific Incorporated (2018), the "Peace Home Center for Girls" in Sta Rosa, Laguna, funded a gift-giving initiative on 14 December 2018 entitled 'The Blessing of Giving' in another arm of "Ang Bahay Parola". The business company played games and gave out gifts and food to the children and employees. In response, the children gave a warm-hearted presentation as a way of saying thank you to the establishment. Taking socially responsible company initiatives is a win-win situation. Not only does the business cater to more socially aware customers and workers, but it can also make a positive difference in the world. In CSR, accountability, and integrity about what the company is doing are key to the public's assurance. CSR will cover a wide range of strategies, from giving a share of the income of a business to non-profit organizations, to providing items of service to a deserving recipient.

As shown in the table, it shows a significant difference with regards to the CSR involvement in the area of goodwill with computed $p$-value of .019 which is less than the .05 alpha levels. Result showed that employees who earned 36,000 to 40,000 have significantly higher level of CSR involvement in terms of goodwill. By being key approximately CSR, golf course and nation clubs can use their great will to advantage themselves, their 
representatives, and most of all the communities where their representatives and visitor live and work. The respondent's magnanimity and volunteer administrations are profitable assets.

Result showed that the group of guests with less than Php 100,000 income has significantly higher level of response in the level of involvement of the Golf Course compared to other income groups. In the article of Mousavi et al. (2013), mentioned that one of the best definitions of Corporate Social Responsibility is that a corporation along with its commercial success maintains all ethical, social and personal values, environmental values and benefits of interest groups. In the other words, Social Responsibility includes corporate manager accountability for legal, social and environmental expectations of interest groups. Considering the relationship between the state and corporate social responsibility leads to that effective implementation of this system increases the level of corporate social responsibility Promoting corporate responsibility will improve interaction between company and community. The other direct advantages of promoting corporate social responsibility includes more access to financial resources resulted from good reputation, risk management and supervision of the affairs of the organization, customer loyalty and interest groups trust to the company.

\section{Conclusion and recommendation}

Respondents from Laguna have a significantly higher response to CSR participation in an environmental activity, volunteering, and goodwill whereas employees who earned 36,000 to 40,000 have significantly higher level of CSR involvement in terms of goodwill. Result showed that the group of guests with less than Php 100,000 income has significantly higher level of response in the level of involvement of the Golf Course compared to other income groups. Based on the result of the study, the research recommends the following: The guest, employees/staff and top management of selected golf course and country clubs need to involve themselves in a more in-depth manner so that they may determine the success of CSR activities based on objectives defined by them. CSR awareness campaigners among their guest, employees/staff and top management of the selected golf course and country club, CSR implementation training and information resources on CSR projects, activities, and practices.

\section{References}

Ahmad, R., Abdul Rahman, R., \& Mohd Anuar, H. (2018). Organizational whistleblowing policy as a corporate social responsibility initiative: Employees' perspectives of moral and religious considerations. The Journal of Social Sciences Research, 4(6), 266-270. https://doi.org/10.32861/jssr.spi6.266.270

Bianca, A. (2018). What are ethical responsibilities in an organization? https://yourbusiness.azcentral.com

Borbon, N. M. D. (2019). A proposed framework of commitment for hotel industry in CALABARZON. Asia Pacific Journal of Education, Arts and Sciences, 6(2), 86-92.

Cycyota, C. S., Ferrante, C. J., \& Schroeder, J. M. (2016). Corporate social responsibility and employee volunteerism: What do the best companies do? Business Horizons, 59(3), 321-329. https://doi.org/10.1016/j.bushor.2016.01.004

Gathering Pacific Consolidated. (2018). The favoring of giving. https://angbahayparola.weebly.com

Kim, K. Whillans, A. Lee, M. Chen, Y., \& VanderWeele, T. (2020). Volunteering and subsequent health and well-being in older adults: An outcome-wide longitudinal approach. American Journal of Preventive Medicine. https://doi.org/10.1016/j.amepre.2020.03.004

Kulej-Dudek, E. (2018). Environment and community involvement as examples of CSR pillars in research in the SME sector in Poland. In K. S. Soliman (Ed.), Proceedings of the 31st International Business Information Management Association Conference, Milan, Italy.

Melo, T., \& Garrido-Morgado, A. (2012). Corporate reputation: A combination of social responsibility and industry. Corporate Social Responsibility and Environmental Management, 19(1), 11-31. https://doi.org/10.1002/csr.260

Mousavi, Z., Beiranvand, F., Moeinfar, Z., \& Amouzesh, N. (2013). Corporate social responsibility. Life Science Journal 10(6), 8-10. 
An evaluation on CSR involvement among the golf courses and country clubs in the Philippines

Oriol Hurtado de Mendoza, C. (2019). Corporate social responsibility in Mahou-San Miguel.

Stawiski, S., Deal, J. J., \& Gentry, W. (2010). Employee perceptions of corporate social responsibility. Center for Creative Leadership. Greensboro, NC. https://doi.org/10.35613/ccl.2011.2022

Suh, Y. J. (2016). The role of relational social capital and communication in the relationship between CSR and employee attitudes: A multilevel analysis. Journal of Leadership \& Organizational Studies, 23(4), 410-423. https://doi.org/10.1177/1548051816637564

UNDP. (2019). Making development co-operation more effective. https://www.undp.org 
Vizconde, A. M. L. 